\title{
2013
}

\section{Rethinking the human right to water: Water access and dispossession in Botswana's Central Kalahari Game Reserve}

\section{Cynthia Morinville and Lucy Rodina}

Institute for Resources, Environment and Sustainability, The University of British Columbia2202 Main Mall, Vancouver, BC V6T 1Z4, CanadaCorresponding author: cynthia.morinville@gmail.com 


\title{
Rethinking the Human Right to Water: Water Access and Dispossession in Botswana's Central Kalahari Game Reserve
}

\begin{abstract}
This paper engages debates regarding the human right to water through an exploration the recent legal battle between San and Bakgalagadi and the government of Botswana regarding access to water in the Central Kalahari Game Reserve. The paper reviews the legal events that led to the realization of the human right to water through a decision of the Court of Appeal of Botswana in 2011 and the discursive context in which these events took place. We offer a contextual evaluation of the processes that allowed the actual realization of the human right to water for the residents of the Central Kalahari Game Reserve, revisiting and extending dominant lines of inquiry related to the human right to water in policy and academic debates. Adding to these discussions, we suggest the use of 'dispossession' as an analytical lens is a useful starting point for a conceptual reframing of the human right to water. Doing so helps to expose some of the problems with the public/private binary, often at the centre of these debates, allowing for greater nuance regarding the potential of the human right to water in different contexts.
\end{abstract}

Keywords: Human Right to Water; Dispossession; Privatization; San and Bakgalagadi; Botswana; Central Kalahari Game Reserve

\section{Introduction}

On April 1, 2010, Survival International, an international advocate for tribal peoples' rights worldwide, published an article entitled "'Pioneering' plan to give Bushmen armbands as tourist lodge opens" (Survival International, 2010). The piece announced that in response to a critique of the "immoral policy" allowing the establishment of tourist lodges with swimming pools in the Central Kalahari Game Reserve (hereafter CKGR), while denying Bushmen access to water, the government of Botswana came up with a plan to provide them with armbands to ensure their safety. The armbands are intended to protect Bushmen "in case they fall in the pool whilst trying to drink it." Tonguein-cheek and making light of the rather dire situation facing the indigenous peoples of the CKGR, the mock article went on to quote the fictitious and aptly named welfare minister, Letthem Drinkbeer:
This scheme shows that we have the welfare of the Bushmen very much in mind. To those who think for some reason that opening lodges for tourists in the Kalahari while we are banning the Bushmen from accessing their water borehole is immoral, I say, 'would you prefer your tourists sweaty?'[...] And as [the Bushmen] should have realized by now, it will be much better for them to go back to the relocation camps, where there is no shortage of home-brew and other alcoholic beverages to quench their thirst, rather than persisting in living on their 'ancestral land' in the Kalahari. (Survival International, 2010)

Foregrounding an absurd declaration, the piece provides a satirical commentary on widely contested state interventions that have long denied San and Bakgalagadi ${ }^{1}$ people of Botswana the ability to reside on their ancestral lands in the CKGR (Hitchcock et al., 2011; 
Resnick, 2009; Saugestad, 2006; Solway, 2009; Taylor, 2007). In 2006, after a decade of persistent social struggles and legal battles that followed the forced relocation of the 1990s, San and Bakgalagadi were legally allowed to return to their traditional lands in the CKGR. However, access to water resources in the reserve remained prohibited, which posed an immense burden on their livelihoods. After continued legal struggle, this time in the Court of Appeal, the situation changed in January 2011 when San and Bakgalagadi finally won their case against the government allowing the appellants to use the borehole at Mothomelo once again, ${ }^{2}$ as well as to drill new boreholes at their own expense (Hitchcock et al., 2011; Botswana Court of Appeal, 2011). This successfully ended a tenyear-long legal struggle over the right to access water in the CKGR and marked a significant triumph for global water justice movements. It also rectified a situation that had granted return to traditional lands, but denied access to water resources used prior to the relocation.

In the policy realm, the increasing interest in the human right to water (hereafter HRW) has gained considerable momentum, particularly coinciding with the United Nations General Assembly's adoption of a resolution recognizing access to clean water and sanitation as a human right on July 28, 2010 (A/RES/64/292 of 28 July 2010). This was further acknowledged by the UN Human Right Council's confirmation that states have a legally binding responsibility to respect, protect and fulfil this right $(\mathrm{A} / \mathrm{HRC} / 15 / 9$ of 6 October 2010). This marked a crucial moment in international water governance discourse by signifying a move towards addressing water inequalities, affirming a universal ideal that all people should have access to water, regardless of ability to pay. As such, the adoption of this resolution marked an important milestone in long-standing international water justice initiatives. Considering the growing acceptance of and support for the HRW and in light of existing calls for more context specific and geographically bounded conceptualizations of the HRW (Sultana and Loftus, 2012, p. 9), we offer a review and a discussion of the outcomes of the legal case granting San and Bakgalagadi the right to water in the CKGR. In this paper, we offer an analysis of court documents and mobilize secondary data related to this case to consider and contribute to on-going academic and policy debates regarding the HRW and its strategic potential for marginalized populations. Further, as we detail, the realization of the human right to water in the CKGR has been crucial for indigenous socio-economic struggles and livelihoods, even in the absence of a constitutional provision guaranteeing the HRW at the national scale. Specifically, our analysis proposes a focus on dispossession processes and seeks to not only lend greater nuance to on-going conceptual-theoretical debates oftentimes concerned with questions of public/private provision, but also to offer an alternative way of evaluating and envisioning, the HRW.

The literature around the HRW presents a range of disparate case studies, as well as conceptual-theoretical debates related to the HRW's potential to secure water access for marginal and vulnerable populations. In particular, among critiques of the concept, there is a concern that the HRW is limited as an approach, given that it might be consistent with privatization trends, or given the western- and individual-centric nature of 'rights talk' (Bakker, 2007; 2010a). We review this discussion in more detail in section 2 . We then go on to more fully outline the historical and legal context in which the Botswana case unfolded in order to offer some reflections on how the HRW played out in section 3. Finally, in section 4, we draw on our case study to revisit key issues related to the HRW concept and offer some nuance regarding its potential as a strategy to open up spaces of negotiation for indigenous and marginalized populations (see also Mirosa and Harris, 2012). While it has been argued that the concept is increasingly used by conflicting agendas and thus risks becoming an 'empty signifier' (Sultana and Loftus, 2012; Bakker, 2007; 2010a), we 
argue that the case at hand does not only offer an example of its 'on the ground' success in securing access to water, but also of how the HRW proved a useful strategy to advance the struggle of San in maintaining traditional livelihoods and access to traditional lands threatened by developmentalist and conservationist policy agendas. We further engage with discussions around the underlying processes that deprived San and Bakgalagadi of their access to water as well as the factors that contributed to the realization of the HRW in this context to argue for a reframing of the concept. Specifically, we propose one possible avenue for enriched discussions through a focus on 'dispossession' processes.

\section{The Human Right to Water Debates}

The HRW has gained significant currency among scholars and policy-makers internationally, particularly among local and global water justice movements (Sultana and Loftus, 2012; Mirosa and Harris, 2012). The HRW was recognized in 2002 by the UN Committee on Economic, Social and Cultural Rights on the basis that it is required for leading a healthy and dignified life and therefore a prerequisite for other rights, such as the right to life and health (Anand, 2007; Brooks, 2007; Cahill, 2005; McCaffrey, 1993). The right to water later gained official international legal recognition as a human right in the UN General Assembly and the UN Human Rights Council in 2010 - an event that arguably marked a significant victory for the global water justice movements who had been fighting for its acceptance at earlier international policy fora (Sultana and Loftus, 2012).

Discussions around the HRW as a concept and a policy mechanism are particularly concerned with its limitations and several scholars have addressed the many challenges facing the concept (see Sultana and Loftus, 2012 for a recent edited collection on the HRW, as well as Mirosa and Harris, 2012; Bakker, 2010a; 2007; Parmar, 2008; Anand, 2007; Mehta, 2006).
Some of the critiques suggest that the HRW is western-centric insofar as it has western origins, and draws on ideas of neutrality, universality, and sense of justice and equity (Mirosa and Harris, 2012; Parmar, 2008; Bakker, 2010a; 2007). The HRW has also been criticized for being inherently individualizing (Sultana and Loftus, 2012) and presenting little concern for context specificity (Mirosa and Harris, 2012; Bakker, 2007). In addition, it is claimed that it is anthropocentric in its focus, privileging the needs of human populations over the needs of other organisms or the ecosystem as a whole (Bakker, 2010a; see Brooks, 2007, for a discussion on the need to extend the definition of the HRW to include the right of water to support ecosystems). Critiques maintain that, as with other human rights, the concept is state-centric given that it depends on states for its adoption and implementation (McCaffrey, 1993). Others have suggested that adopting the HRW is only a formal provision, a change on paper, oftentimes facing significant problems of implementation and enforcement (Mirosa and Harris, 2012; Bakker, 2010a; 2007; Anand, 2007; Mehta, 2006).

Bakker $(2007 ; 2010 a)$, in a critique that has gained much traction, contends that the HRW discourse has been largely conflated with commons/commodity or public/private debates in which water justice activists engage the language of HRW in an attempt to resist privatization - a strategy that she suggests fundamentally undermines or limits its potential as a social justice strategy (see also Sultana and Loftus, 2012). She concludes that the concept is intrinsically flawed and ill guided to resist current shifts towards neoliberal water governance as

Pursuing a 'human right to water' as an anti-privatization campaign makes three strategic errors: conflating human rights and property rights; failing to distinguish between different types of property rights and service delivery models; and thereby failing to foreclose the possibility of 
increasing private sector involvement in water supply (Bakker, 2007, p. 439).

Parmar (2008) similarly warns us that the HRW is highly paradoxical. It can, at times, be used to "interrogate the barbarism of power", but can also be used as a disguise by this very operation of power rendering it "ultimately, that which we cannot not want" (p. 82). Parmar here specifically refers to how the private sector, a very unlikely supporter of the HRW, has emerged as one of its most vocal and powerful proponents, making for a curious alignment (an issue also highlighted in Bakker's analysis, 2007). Related to this, Sultana and Loftus (2012) caution that the HRW risks becoming an empty signifier, a vacuous legal term adopted by both political progressives and conservatives without real impact on locally defined challenges of water governance (p. 2).

On the other hand, the HRW has also been described as a potentially powerful tool for marginalized, dispossessed and vulnerable communities to negotiate and claim access to water. The HRW is thus seen as instrumental and potentially effective for marginalized populations given its potential to open up new spaces of negotiation around water issues (Sultana and Loftus, 2012; Mirosa and Harris, 2012). This contention suggests that the HRW may serve as a 'means' in broader struggles for social justice. In her recent book, Bakker (2010a) maintains that although the critiques (as presented above) are valid, concept holds some aspirational value.

The human right to water is a useful tactic for those without access to legitimize their struggles, not only for water, but also for human dignity. In this aspirational sense, the $[$ HRW] is a valuable tool...In other words, human rights are not the solution but are rather a strategy for creating the context in which claims for social justice can be pursued (Bakker, 2010a, p. 159).

Parmar (2008) also argues that despite the limitations of the HRW inherent in what she sees as the "rigid script of human rights law" and the "western liberal paradigm" (p. 81), the greatest potential for transformation lies in its aspirational tone. Mirosa and Harris (2012) reach a somewhat different conclusion regarding the usefulness and constraints of the HRW as a political strategy. Through three case studies, they present evidence that the HRW can be useful not only aspirationally, but also as a potentially effective tool to promote access to water, particularly given the contextual realities that might be present on the ground. The authors maintain that the concept allows for a focus on 'end goals' in terms of universal access to water regardless of ability to pay that is

...particularly crucial given that much of the recent debate on water governance has been heavily focused on provision (i.e. dominated by public versus private discussions) effectively sidelining any meaningful discussion of end goals. (p. 936)

Mirosa and Harris thus conclude that given antiprivatization campaigns' focus on questions of responsibility for provision and the HRW's explicit attention to questions of access, the convergence of the two discourses makes strategic sense. In other words, given the historic trajectories of neoliberal water governance, and the ways in which the debate has centred around provision (and ideas associated with privatization such as efficiency or cost recovery), the HRW and its absolute focus on universal access (i.e. equity rather than efficiency focus) makes strategic sense to counter these trends. Sultana and Loftus (2012) further argue that the HRW opens up both discursive and policy spaces that can enable "more equitable possibilities to be struggled for, envisioned, and plausible tactics for distributive justice and democratic processes to be pursued" (p. 4).

We agree with several others that the actual realization of the right to water depends on context-specific governance processes, mechanisms and actors (Sultana and Loftus, 2012; Mirosa and Harris, 2012) as well as socioeconomic struggles as evidenced in the case at hand. As such, we present an exploration of a 
concrete realization of HRW, grounded in San and Bakgalagadi's historical, geographical and cultural realities. Through an investigation of the legal battle for water access and the factors that helped realize the HRW in this particular case i.e. the case's position in long-term on-going social justice struggles to access traditional lands and livelihoods as well as the support from the international indigenous rights and water justice movements -we argue that the HRW effectively opened up avenues for negotiation by relocating long-lasting subsistence struggles on a new playing field. The case, in this sense, serves to add to the suite of other case studies that explore the potential of the HRW (Mirosa and Harris 2012), and offers a clear illustration of the HRW's strategic potential. Following the presentation of the case study, we however turn to other dimensions of the HRW debates in section 4 in order to address broader conceptual issues and offer new dimensions and avenues for conceptual reframing.

\section{San and Bakgalagadi and the Right to Water}

San people are known locally, regionally and internationally under several different appellations - Bushmen, Bushpeople, Basarwa (the official name in Botswana), N/oakwe, N/oakwe, Kwe (Saugestad, 2001, p. 28). These names refer to a heterogeneous group of peoples who have predominantly resided in the contemporary contexts of Botswana, Namibia, South Africa, Zimbabwe, Lesotho, Mozambique, Swaziland, and Angola. San, in particular, is often used to represent the group internationally. The San groups in the case study discussed in this paper specifically include the G/ui (or G/wi) and $\mathrm{G} /$ /ana. Bakgalagadi people, while being a different linguistic group, also reside in the region and, although debates regarding the exact length of time Bakgalagadi have been in the Central Kalahari are inconclusive, evidence such as oral history suggests they have been present in the region for several hundreds of years (Hitchcock et al., 2011; Good, 2008) ${ }^{3}$. In line with the details of the court case, whose applicants were representatives of both San and Bakgalagadi as indigenous peoples of the CKGR, this paper we use the names San and Bakgalagadi to depict the people concerned by the relocation processes and the court case, and not the broader ethnic and linguistic groups.

Traditionally, San livelihoods relied centrally on foraging, hunting and gathering until political shifts in the $19^{\text {th }}$ century resulted in a hierarchical system whereby elite groups took them in serfdom, with inequalities persisting today (Hitchcock, 2002; Good, 1999; Sylvain, 2008; Sporton and Thomas, 2002; Solway, 2009; and Sarkin and Cook, 2012). Today, San form a majority amongst Remote Area Dweller (RAD) groups in Botswana and maintain traditional hunting-gathering activities to supplement herding and livestock production (Good, 1999; 2008).

Historically, indigenous residents of the Kalahari lived either in small sedentary communities near water pans or boreholes, or moved around to collect resources (Hitchcock et al., 2011). San predominantly relied on surface water or occasional rain water harvesting when surface water sources were unavailable (Hitchcock et al., 2011). In the 1930s, a stronger focus was placed on economic development in the Kalahari and brought large cattle herding ventures to the CKGR region, often dominated by Tswana ${ }^{4}$ herders. This was accompanied by the introduction of new technology allowing the sinking of boreholes by local cattle owners (Sarkin and Cook, 2012). In some instances communal access to water points was replaced by syndicated ownership, which favoured the political elite and cattle owners and contributed to the marginalization of small scale herders and hunter-gatherers, such as the San (Sarkin and Cook, 2012).

Since the colonial period, the region has been considered a vast and untapped resource, frequently overlooking the fact that groups such as San have historically inhabited many areas (Taylor, 2003; Sporton and Thomas, 2002; 
Debenham, 1952). This situation, of course, parallels numerous contexts where traditional populations and livelihoods are considered to compete with conservation goals oftentimes leading to the removal of these populations and activities from conservation areas (e.g., see Neumann, 1997; 1995; Turner, 1999). In 1961, the government of Botswana gave the Central Kalahari a conservation status with the dual goal to protect wildlife resources and to reserve sufficient land for traditional livelihoods in the area. The resources of the area have also more recently been exploited by the wildlife and ecotourist industry and the diamond industry with DeBeers and later Gem Diamonds/Gope Exploration Company (Pty) drilling diamond prospecting boreholes (Saugestad, 2011; Hitchcock et al., 2011).

Following its establishment as a natural conservation area in the early 1960s, provisions were made to reserve sufficient traditional land for the use of hunter-gatherer communities in the Central Kalahari (Saugestad, 2011, Sarkin and Cook, 2012). In the 1960s through the 1980s, the government of Botswana provided services inside the reserve, including a borehole at the largest settlement in the area - !Xade (Saugestad, 2011). ${ }^{5}$ From the 1980 s onwards, concerns were voiced regarding the feasibility of continued services provision. Then, in 1986, without consultation with residents of the CKGR, the government of Botswana stated that the area should be maintained as a nature reserve (Saugestad, 2011). Between 1986 and 1997 the government actively encouraged inhabitants to relocate outside of the area in 'service centres' (Hitchcock, 2002; Hitchcock et al., 2011). These relocation zones ostensibly aimed to provide the residents of CKGR with access to services and opportunities for alternative socio-economic development (Hitchcock, 2002)..The service centres would include education and health facilities and offer alternative employment for the relocated residents. They would also serve as base for the administration of labour-based drought relief, feeding programmes, and also
Remote Area Development Initiatives (Sporton and Thomas, 2002; Solway 1994). In reality, however, these services were slow to materialize in the new settlement areas and resettled people expressed high levels of dissatisfaction (Hitchcock et al., 2011; Resnick, 2009) bringing commentators to suggest that the resettlement camps were meant to accommodate residents but not to support traditional livelihoods (Sporton and Thomas, 2002).

The rationale behind the relocation project as presented by the government of Botswana was threefold- (1) it was cost-prohibitive for the government to provide services to remote and dispersed populations; (2) people and wildlife were incompatible in the reserve, ${ }^{6}$ and (3) San would be better off in locations closer to developed infrastructure. This reasoning is consistent with the environmental conservation policy in the area as well as the national water strategy plan that focused on control of water supply and provision due to scarcity. ${ }^{7}$

The official relocation programme was initiated in 1997 when, according to some estimates, 1239 people were relocated to New !Xade and 500 to Kaudwane, leaving between 420 and 450 indigenous residents in the CKGR (Hitchcock et al., 2011, p.69). This was followed by a second wave of relocations in 2002, moving 342 people to New !Xade, 179 people to Kaudwane and another 17 to a new settlement at /Xeri (Hitchcock et al., 2011, p.69) ${ }^{8}$ (see Figure 1). To reinforce the second phase of the removal, the government terminated the provision of services to area and the Wildlife Department sealed water boreholes (Resnick, 2009; Hitchcock et al., 2011; Sarkin and Cook, 2012), including the Mothomelo borehole, one of the major sources of potable water in the area, and the only borehole under San and Bakgalagadi control. Furthermore, according to the court records, at the time of the 2002 relocations, Mothomelo was the only permanent water source in the area, whereas the other settlements (with the exception of Gope) depended on rainwater and water provided via truck delivery by the 
authorities (Roy Sesana and Others vs Government of Republic of Botswana, 2006, p. 80). This effectively prevented local San residents from accessing water and thus maintaining their livelihoods in the CKGR (Hitchcock et al., 2011).

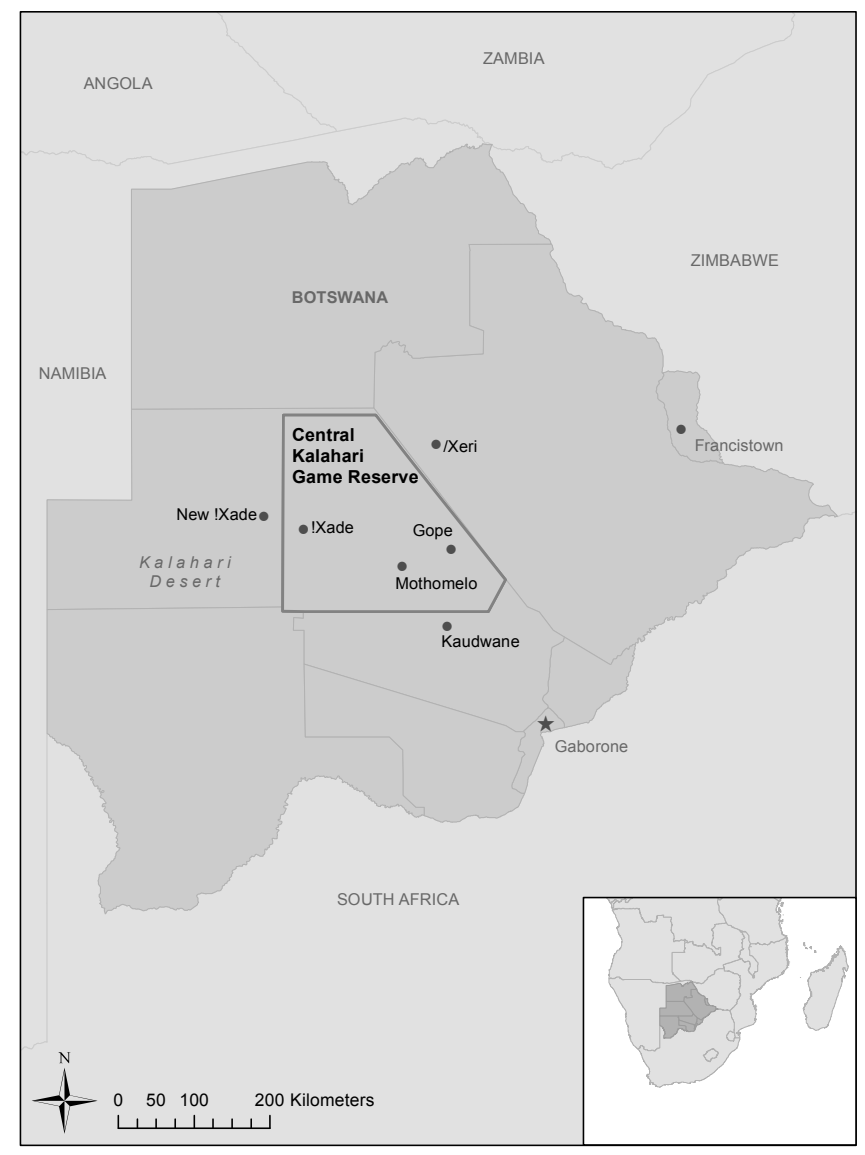

Fig. 1. Botswana's Central Kalahari Gama Reserve (CKGR) (adapted from Hitchcock et al., 2011).

Rights and control over water resources in Botswana and particularly in the CKGR is a complex issue. According to the customary law, open surface water is publicly owned and can be used by anyone, whereas sub-surface water, involving capital costs and labour for its extraction, is private. Wells, hand dug sip-wells and other water sources are often managed communally and in order to secure continuous access to water, residents often rely on social relationships and kinship ties (Hitchcock et al., 2011). On the other hand, water points such as prospecting boreholes drilled by the mining industries, as well as water sources made available for tourist lodges, are either private or controlled by the Department of Wildlife and National Parks (Saugestad, 2011). As their status is questionable, it is unclear whether they are available for domestic water use by indigenous residents of the area. Following the relocation, the remaining local residents were not allowed to drill new boreholes nor could they equip and use existing boreholes drilled by mining companies. Whereas before the relocation the Department of Wildlife and National Parks delivered water in tanks to some settlements in the CKGR to be used by local residents as well as by private tourist or mining companies, in 2002 water provision services or access to boreholes for the indigenous communities residing in CKGR were no longer in service (Saugestad, 2011). Furthermore, upon return to their ancestral lands in 2006, San and Bakgalagadi risked arrest if they attempted to drill or re-commission existing boreholes (Hitchcock et al., 2011). As the residents could not access potable sub-surface water, they relied on open surface water (i.e. ponds, rainwater $)^{9}$ which everyone is free to use under Botswana's customary law (Hitchcock et al., 2011).

The residents of the CKGR, led by Roy Sesana, sought legal redress against the government of Botswana with the support of a number of local organizations such as the Kuru Family of Organizations (KFO), First People of the Kalahari (FPK) and the Working Group on Indigenous Minorities in Southern Africa (WIMSA), as well as a number of international human advocacy groups (e.g., Survival International, involved more recently in the legal case). They did so on the grounds of unlawful displacement and sought to return to their lands and traditional livelihoods in the CKGR (for the role of international movements and activist organizations in supporting the rights of San, see Munzer and Simon, 2009; Resnick, 2009; Saugestad, 2006; Taylor, 2007). The struggle between San and the government has been 
dominated by two major discursive themes: indigenous cultural rights and land use rights (Hitchcock et al., 2011, pp. 63-64; Cook and Sarkin, 2009; Hays and Biesele, 2011). Since the late 1980s San social movements have mobilized and protested to gain social and cultural rights, as well as to retain land and resource ownership.

The mobilization of indigenous peoples of the Kalahari - mainly through the establishment of community-based institutions and nongovernmental organizations (NGOs) - was largely founded around the issue of the resettlement of San and was centred on promoting economic and cultural rights aiming to preserve San's livelihoods in the CKGR. San used the discourse of indigeneity to re-assert their rights as a culturally different people historically marginalized by the assimilationist policies. The growing international recognition around indigenous peoples' rights created the legal and discursive space to oppose the government of Botswana's strict approach to nation building that had long refused to formally acknowledge San as an indigenous minority. In line with Botswana's explicit anti-apartheid strategy of avoidance of policies that differentiate rights based on ethnicity, the government of Botswana asserted in a statement to the Human Rights Commission in 1997 that all people of Botswana have equal rights and that the preservation of the land and its resources for future generations was a major national priority (Hitchcock, 2002). This lack of formal recognition not only served to undermine San's 'indigenous' claims for the right to live in their ancestral lands ${ }^{10}$ (Cook and Sarkin, 2009; Hitchcock et al., 2011; Saugestad, 2001), but also allowed for conservationist agendas to gain traction, especially since protected areas such as the CKGR are framed as preserving nature for future generations rather than focusing on current conflicts with indigenous residents. With regards to the CKGR case specifically, the government presented the conflict with San as a land use dispute in which the state prioritized nature conservation over livelihood concerns, and cast traditional livelihoods of mobile hunter-gatherers as incompatible with the goal of conserving wildlife (cf. Turner, 1999 for a similar case from Western Africa). This tactic can also be seen as linked to growing international concern over biodiversity, as well as interest in capturing revenue possibilities from safari travel and ecotourism. The economic imperatives behind some of these strategies are further highlighted by the fact that even with declaring these areas as conservation spaces, the government nonetheless allowed mining and tourist industries to flourish in the CKGR, which provoked international outrage.

On February 19, 2002, a land and resource rights case was brought to the High Court by 243 relocated residents of the CKGR who sued the government for forceful relocation, termination of service provision, including the daily provision of drinking water and the maintenance of boreholes, among others (Roy Sesana and Others vs Government of Republic of Botswana, 2006). This case was dismissed and brought back to the High Court in 2004. It was not resolved until December 2006 when the court ruled the above-mentioned actions taken by the government unlawful, thereby restoring both land and subsistence hunting rights and allowing a return to the CKGR, but only for the 189 individuals that remained as applicants at the time (Saugestad, 2011). Even as boreholes and water access was specifically mentioned in the case, the court decision did not address the question of provision of water and other services (Botswana High Court, 2006; Hitchcock et al., 2011; Saugestad, 2006). In fact, the court ruled that the termination of services was neither unlawful nor unconstitutional and that the government was not obliged to restore basic and essential services (Saugestad, 2011). As a result, even though the applicants were able to return to their traditional lands in CKGR, they could not access previously used water sources. They faced arrest if they attempted to drill or recommissioned existing boreholes and could not demand water services, which ultimately 
prohibited them from securing their livelihoods in the reserve. The government thus effectively denied access to water by prohibiting access to a major water source - the borehole at Mothomelo - on land the applicants were recognized to be in lawful possession of (Hitchcock et al., 2011; Saugestad, 2011). The ruling was deemed successful by many advocates despite the continuing inaccess to water resources within the reserve for the relocated residents. The authorities maintained that the residents were allowed to make their own arrangements to bring water in the reserve for their subsistence needs, but that the government had no direct obligation to provide these services (Saugestad, 2011). The international community in support of displaced San criticized the government of Botswana for allowing mining and tourist industries to use water resources available in the reserve while continuing to deny access to San and Balgalagadi (as referenced in the mock article in the introduction to this paper).

The debate around water access in the CKGR continued. In 2010, the residents of CKGR filed an appeal, challenging the earlier High Court refusal to acknowledge San the right to recommission, at their own expense, the Mothomelo borehole and sink other wells and boreholes for domestic use. This appeal was based on the High Court's ruling of 2006 and acknowledged that the San people in CKGR were historically dependent on the availability of water in the disputed area (Botswana Court of Appeal, 2011). On January 27, 2011, The Botswana's Court of Appeal ruled that the appellants - the lawful occupiers of the land, and not the broader San people -"have the right to sink a borehole for domestic purposes, or recommission at their own expense the Mothomelo borehole without the need for a water right" (Botswana Court of Appeal, 2011). The decision eventually ended the nearly ten-year-long legal battle regarding water access in the CKGR that had started with the court case of 2002 and was only resolved with the ruling of the Court of Appeal in 2011. ${ }^{11}$

\section{Discussion}

Coinciding with the international community's growing focus on the HRW and the UN General Assembly resolution of July 28, 2010 recognizing access to clean water and sanitation as a human right (A/RES/64/292 of 28 July 2010), the victory for the San and Bakgalagadi in terms of water access in the CKGR has been celebrated in the media as a human rights victory (e.g., BBC 2011; Survival International, 2011a). It is however important to acknowledge that while San and Bakgalagadi successfully challenged the government of Botswana in court and, as a result, eventually gained rights to both land and water, this did not result in government responsibility to actually provide water to these populations in the CKGR. Indeed, as other commentators have pointed out, where the state of Botswana (through its judicial apparatus) allowed San the right to access water in the CKGR, it was not required to ensure this access in any real sense (Saugestad, 2011).

In the remainder of this section, we examine the realization of the HRW in the case of the CKGR and argue that in order to assess its full potential, the factors underlying its realization must be considered more closely. While we agree with others that have recognised the aspirational potential of the HRW and the resulting usefulness of the concept as a strategy to secure access for marginalized groups (Mirosa and Harris, 2012; Sultana and Loftus, 2012; Parmar, 2008), we contend our analysis must not stop here. We suggest there is more to the HRW than a strategic tool employed by marginal groups in an ad hoc manner. Our efforts in this section thus aim to highlight some of the underlying trends and processes at play and offer one possible avenue for conceptual reframing using the lens of 'dispossession'. As such, our efforts can also be read as an attempt to answer raised concerns regarding the risk of the HRW becoming an empty signifier given its current tokenization through, for example, its mobilization by the proponents of conflicting 
agendas regarding water provision (Sultana and Loftus, 2012; Parmar, 2008).

As we have traced in section 3, our case study presents clear linkages between land rights and water rights as well as to broader livelihood struggles for residents of the CKGR. While the San and Bakgalagadi applicants (note again, not all indigenous peoples of the CKGR) were recognized to be in lawful possession of their ancestral lands and allowed to return to the reserve in 2006, the lack of access to the main water sources in the area effectively limited their ability to maintain their livelihoods in the reserve. This case thus first suggests land rights and water rights cannot be decoupled and are rather mutually dependent; seeing them as separate and stand-alone issues might be misguided from a livelihood perspective. Indeed, as evident in this case, granting (de jure) rights to access ancestral land in the CKGR, as explicit in the 2006 court ruling, resulted in limited actual (de facto) gains for San as long as water access was denied in the reserve. While we focus our discussion around questions of water access and the HRW, we acknowledge these interdependencies and the relations to the longterm dispute between San and the government of Botswana, as well as to parallel discussions and literatures concerned with the establishment of protected areas and indigenous peoples' rights and livelihoods (e.g., Cook and Sarkin, 2009; Hays and Biesele, 2011; Hitchcock, 1995).

This relationship to land, we believe, offers an interesting point of departure for our inquiry around questions of dispossession. In a discussion of the Kalahari, Sporton and Thomas highlight the linkages between processes by which land and water are being fenced off and global economic patterns in the area and argue:

The Kalahari today is a landscape crisscrossed with fences, populated by cattle, and inhabited by 'real' people for whom contemporary enviro-social relations and livelihood outcomes are both embedded within a long and complex history of social and environmental change and increasingly subject to the commercial pressures of the global economy (Sporton and Thomas, 2002, p. 217).

This vignette, of course, does not depict an unusual scene. The complex relationship between capitalism and processes of land enclosure can be traced back to Marx's discussion of 'primitive accumulation' in England and has been at the centre of much critical scholarship within the disciplines of geography and political economy (e.g., De Angelis, 2001; 2004; Glassman, 2006; Hart, 2002; 2006; Harvey, 2003; Perelman, 2000; 2007). While our focus here does not propose an exhaustive discussion of processes of land enclosure in the Kalahari, we wish to draw attention to the simultaneous enclosure of land and water. These linkages have more recently been recognized in discussions addressing the conjunctures between land and water grabbing with commentators suggesting that large-scale land grabs also result in processes of water grabbing, and that access to hydrological resources might, in some cases, constitute the driving force for such land enclosure (e.g., Mehta et al., 2012).

Whereas some have called to move beyond public/private debates regarding the HRW (e.g., Parmar, 2008), we would argue this should not deflect our attention from the need to look squarely at capitalist processes. Highlighting the course of land enclosure and primitive accumulation that took place in the Kalahari, as well as their relationship to water resources, is fruitful for our analysis of the HRW insofar as it allows us to recognize that while this context differs from the widely documented cases of private sector involvement in urban water provision (e.g., Bakker, 2010a; McDonald and Ruiters, 2005; Swyngedouw, 2005), the interests and involvement of capital (and of the state) are central to the CKGR story. Specifically, private resorts have secured access to the land, as well as to the hydrological resources of the region, in turn used for various activities from cooking and filling swimming pools in tourist lodges and 
resorts, to mining prospection and diamond extraction. This, more importantly, went hand in hand with, and to some extent relied on, state-led relocation and denial of access to land and water for the former residents of the CKGR, essentially constituting what we argue is a process of dispossession. $^{12}$

It is true that the genealogy of the CKGR as a protected area, as we have outlined in section 3, undeniably predates the involvement of private ecotourism and extraction activities in the reserve. Recognizing the history through which the CKGR was established must however not shadow the repeated and on-going processes of dispossession that marked the region through the evolution of the reserve and the different waves of resettlements (see also Good, 2008 for a historical analysis of dispossession in Botswana; $\mathrm{Li}, 2010$ for a meta-analysis of dispossessions in different locales since the colonization era). Renewed scholarly interest in primitive accumulation in recent years (e.g., Harvey, 2003; De Angelis, 2001; Glassman, 2006) has highlighted that the separation of producers from their means of production occurs through both primitive accumulation processes and accumulation proper (De Angelis, 2001; Glassman, 2006). Harvey's concept of 'accumulation by dispossession' (2003) further underlines that such processes do not belong to a historical past, as the use of the word 'primitive' might otherwise suggest, but are rather on-going and continuous. In this sense, the gradual enclosure of the reserve in the Central Kalahari, the different waves of relocation, and decommission of boreholes must be read in parallel to a trajectory of dispossession and stateled reforms in the interest of capital accumulation.

Linkages between privatization, enclosure, dispossession and processes of accumulation are, of course, well recognized (e.g., Roberts, 2008; Bakker, 2010b; Harvey, 2003; McCarthy, 2004; von Werlhof, 2000). Roberts (2008), in an insightful review of the concept of accumulation and its relation to the environmental commons (and particularly hydrological resources), maintains that when discussing the concept of 'accumulation by dispossession', Harvey (2003) identifies both privatization and enclosure of the environmental commons as key mechanisms for accumulation processes. Von Werlhof similarly argues that accumulation includes, among others processes, "the separation of the public from its property through privatization and the enclosure of the environmental commons" (2000, pp. 738739). Furthermore, De Angelis (2004) suggests that primitive accumulation relies on separations between the producers and the means of production, which occur as new spheres are colonized by capital, or when social spaces formerly identified as commons are enclosed (see Roberts, 2008). Lastly, while significant attention has been paid to the impacts of accumulation on relations of production, Roberts (2008) maintains that tracing the impacts of these processes on social reproduction is less common. Given water's necessity for life, however, the connection between processes of accumulation and their implication for social reproduction is clear.

Acknowledging the parallels between these processes is particularly important for our discussion insofar as the links between dispossession and water resources have often been equated with discussions of privatization. In fact, consider Swyngedouw's assertion that "the official terminology for 'accumulation by dispossession' is of course 'privatization"' (2005, p. 82; see also Roberts, 2008; McDonald and Ruiters, 2005; Bakker, 2007; 2010a; 2010b). Links between 'accumulation by dispossession', or 'primitive accumulation' of hydrological resources and processes of enclosures, through the establishment of protected areas (as in this case) or instances of land and water grabs, are much less common. Our analysis suggests, however, that these may be important underlying processes that must be directly considered rather than sidelined to dominant concerns with privatization, and public/private provision debates. 
As discussed in section 2, many have considered the importance (or limitations) of the HRW in relation to such public/private provision debates. We would however argue that considering the HRW's potential through a narrow focus on privatization is limiting on at least two levels. First, to echo Parmar (2008), as most water privatization efforts are on-going in urban areas, where there is sufficient density to consider the possibility of profit, ${ }^{13}$ the debate has mainly been centred on urban contexts omitting careful considerations of the relevance of the HRW in contexts such as the CKGR. To be meaningful, the HRW must rather go beyond this debate. Second, a narrow focus on privatization processes might also obscure important, yet largely overlooked, underlying processes of dispossession. Indeed, while the HRW has often been cast, in both academic and activists debates, as a strategy to oppose the privatization of provision systems, we see its true potential rather lying in its ability to contest instances of dispossession. ${ }^{14}$ This, in turn, infers that although the HRW might be concordant with private property rights and private water provision schemes (Bakker, 2007; 2010a), its potential remains in its ability to challenge the cases in which such privatization might result in acts of dispossession and water inaccess for marginalized populations. In other words, reconceptualizing the HRW through a focus on dispossession opens further avenues for populations dispossessed by either the privatization or the enclosure of hydrological resources to engage the HRW beyond its aspirational sense.

In sum, our analysis proposes that HRW holds considerable potential when mobilized to oppose underlying processes of dispossession whereby people are denied access to water of sufficient quality and quantity necessary for both production and social reproduction. Furthermore, we suggest that thinking about the HRW through the lens of dispossession can be a useful step in broadening and further grounding our analysis of the HRW concept. In the first instance, it allows a move beyond the narrow confines of the public/private debates, potentially sidestepping some of the concerns related to the relationship between HRW and privatization. Furthermore, an emphasis on dispossession helps to move away from a disproportionate focus on urban centres, enabling a broader conceptualization that includes other sites, spaces and contexts as well as considers water in both its productive and social reproductive roles. Doing so, we suggest, is helpful to recognize that there is more to the HRW than an aspirational strategy for marginalized communities and/or a compatibility with privatization schemes. As such, considering the HRW through a lens on dispossession offers alternative avenues to consider how and when the HRW might or might not prove a useful and productive strategy.

\section{Conclusion}

Through an exploration of the recent court case concerned with San and Bakgalagadi's right to access water in the CKGR, this paper engages with discussions related to the HRW's strategic potential and aims to shed light on the underexplored dimension of dispossession, attend to the importance of context in considering the HRW, as well as lend greater nuance to other aspects of the on-going conceptual-theoretical debates related to the term and its implementation.

Our primary intention in exploring the case at hand is to propose an alternative way of evaluating, but also of envisioning, the HRW. We argue that alternative conceptualizations are much needed at this point if we are to avoid further entanglement in overly simplistic binaries concerned with public/private provision and overlooking the nuances of contextualities. Without attention to such details and nuances, we concur that the HRW risks losing its critical edge (Sultana and Loftus, 2012).

Specifically, we have highlighted how a context where private water provision is not central allows us to recognize other factors (e.g., enclosure) and underlying processes (i.e. 
dispossession) that, we suggest, are crucial to understanding the potential of the HRW. In this sense, we echo Mirosa and Harris (2012) as they recognize "the importance of context specificity to conditioning the variable limits and opportunities associated with any strategy or concept" (p. 937), and would add, in conditioning our analyses of the HRW. The CKGR context was not only crucial in allowing for context-specific outcomes, but more importantly in forcing a shift in our analytical gaze to consider the different meaning and potential for the HRW beyond the urban sphere, and outside of the narrow public/private provision binary.

Acknowledging that access to water is an indivisible part of livelihoods, we argue that a broader conceptualisation of the HRW focused on dispossession and its concomitant implications for questions of social reproduction, livelihoods and subsistence can be a productive point of departure to open up new lines of inquiry. The human right to water discourse has

\section{References}

Amenga-Etego, R.N., Grusky, S., 2005. The new face of conditionalities: the World Bank and water privatization in Ghana. In: McDonald, D.A., Ruiters, G. (Eds.) The Age of Commodity: Water Privatization in Southern Africa, Earthscan, London, pp. 275-291.

Anand, P. B., 2007. Right To Water And Access To Water: An Assessment. Journal of International Development, 19 (4), 511-526.

Bakker, K. 2007. The "Commons" Versus the "Commodity": Alter-globalization, Anti-privatization and the Human Right to Water in the Global South. Antipode 39 (3), 430-455.

Bakker, K., 2010a. Privatizing Water: Governance Failure and the world's urban crisis. Cornell University Press, Ithaca and London.

Bakker, K., 2010b. The limits of "neoliberal natures": Debating green neoliberalism. Progress in Human Geography, 34 (6), 715-735.

BBC News, 2011. January 27. Botswana Bushmen win back rights to Kalahari water. a strategic potential to not only ensure physical access to water, but also to advance claims in broader social justice contexts, as in the case with San of the Central Kalahari, whose return to their traditional lands in the CKGR was contingent to access to water in the reserve.

We nonetheless consider that scholarly interest in the HRW must move beyond the presentation of multiple case studies and their particularities. If we are to further our understanding, evaluation and appreciation of the HRW, systematic efforts must be deployed to understand the underlying factors and processes at play for the realization of the HRW across cases and contexts. Furthermore, we believe debates concerned with the potential and limitations of HRW as a strategy would benefit from a meta-level analysis, to explore the possibility of existing patterns. A focus on dispossession, might, in this sense, provide some pathways for further exploration.

http://www.bbc.co.uk/news/world-africa-12300285. (last accessed 31/03/2012).

Botswana High Court, 2006. Roy Sesana and Others v Attorney General, Misca no. 52-2002. Lobatse. http://www.saflii.org/bw/cases/BWHC/2006/1.html. (last accessed 25/05/2012).

Botswana Court of Appeal, 2011. Matsipane Mosetlhanyane and Others v Attorney General, no. CACLB-074-10. Lobatse. http://assets.survivalinternational.org/documents/545

/bushmen-water-appeal-judgement-jan-2011.pdf (last accessed 25/05/2012).

Brenner, N., Peck, J., Theodore, N. 2010. Variegated neoliberalization: geographies, modalities, pathways. Global Networks, 10 (2), 182-222.

Brooks, D.B., 2007. Human Rights to Water in North Africa and the Middle East: What is New and What is Not; What is Important and What is Not. International 
Journal of Water Resources Development, 23 (2), 227241.

Bywater, K., 2012. Anti-privatization struggles and the right to water in India: Engendering cultures of opposition. In: Sultana, F., Loftus, A. (Eds.) The Right to Water: Politics, Governance and Social Struggles. Earthscan, London and New York, pp. 206-222.

Cahill, A., 2005. 'The Human Right to Water - A Right of Unique Status': The Legal Status and Normative Content of the Right to Water. The International Journal of Human Rights, 9 (3), 389-410.

Cook, A., Sarkin, J., 2009. Who Is Indigenous?: Indigenous Rights Globally, in Africa, and Among the San in Botswana. Tulane Journal of International and Comparative Law, 18, 93-130.

De Angelis, M., 2001. Marx and primitive accumulation: The continuous character of capital's "enclosures". The Commoner 2, 1-22.

De Angelis, M., 2004. Separating the doing and the deed: Capital and the continuous character of enclosures. Historical Materialism 12 (2), 57-87

Debenham, F., 1952. The Kalahari Today. Geographical Journal, 18, 12-23.

Department of Water Affairs, Botswana, 1999. Water Conservation Strategy Framework. http://www.orangesenqurak.org/UserFiles/File/Nationa 1\%20Water\%20Departments/Botswana/National\%20W ater $\% 20$ Conservation $\% 20$ Policy $\% 20$ and $\% 20$ Strategy $\%$ 201999.pdf. (last accessed 25/05/2012).

Gem Diamonds, 2011a. June 20. Regulatory News: Borehole Drilling Programme for Residents of the Central Kalahari Game Reserve Commences. http://www.gemdiamonds.com/gem/en/investors/regula tory-news/?ref=19. (last accessed 18/06/2013).

Gem Diamonds, 2011b. August 10. Gem Diamonds Botswana and Vox United to Hand Over Boreholes to Residents of the Central Kalahari Game Reserve (CKGR) in Botswana.

http://www.gemdiamonds.com/gem/en/investors/regula tory-news/?ref=16. (last accessed 18/06/2013).

Glassman, J., 2006. Primitive accumulation, accumulation by dispossession, accumulation by "extra-economic" means. Progress in Human Geography 30, 608-625.

Good, K., 1999. The state and extreme poverty in Botswana: the San and destitutes. The Journal of Modern African Studies 37 (2), 185-205.
Good, K., 2008. Diamonds, Dispossession and Democracy in Botswana. James Currey and Jacana Media, Suffolk, UK and Auckland, SA.

Hart, G., 2002. Disabling globalization. University of California Press. Berkeley and Los Angeles.

Hart, G., 2006. Denaturalizing dispossession: Critical ethnography in the age of resurgent imperialism. Antipode 38, 977-1004.

Harvey, D., 2003a. The New Imperialism. Oxford University Press, Oxford and New York.

Hays, J., Biesele, M., 2011. Indigenous rights in southern Africa: international mechanisms and local contexts. The International Journal of Human Rights, 15 (1), 110 .

Hitchcock, R., 2002. 'We are the First People': Land, Natural Resources and Identity in the Central Kalahari, Botswana. Journal of Southern African Studies 28 (4): 797-824.

Hitchcock, R., 1995. Centralization, Resource Depletion, and Coercive Conservation Among the Tyua of the Northeastern Kalahari. Human Ecology, 23 (2), 169198.

Hitchcock, R., Sapignoli, M., Babchuk, W., 2011. What About Rights? Settlements, subsistence, and livelihood security among Central Kalahari San and Bakgalagadi. The International Journal of Human Rights 15 (1): 6288 .

Li, T.M., 2010. Indigeneity, Capitalism, and the Management of Dispossession. Current Anthropology 51, 385-414.

McCaffrey, S., 1993. Human Right to Water: Domestic and International Implications. Georgetown International Environmental Law Review, 5, 1-25.

McCarthy, J., 2004. Privatizing conditions of production: trade agreements as neoliberal environmental governance. Geoforum, 35 (3), 327-341.

McDonald, D.A., Ruiters, G. (Eds.), 2005. The Age of Commodity: Water Privatization in Southern Africa, Earthscan, London

Mehta, L., 2006. Do human rights make a difference to poor and vulnerable people? Accountability for the right to water in South Africa. In: Newell, P., Wheeler, J., (Eds.) Rights, Resources and Accountability. Zed Books, New York, pp. 63-78. 
Mehta, L., Veldwisch, G.J., Franco, J., 2012. Introduction to the Special Issue: Water grabbing? Focus on the (re) appropriation of finite water resources. Water Alternatives 5, 193-207.

Mirosa, O., Harris, L., 2012. Human Right to Water: Contemporary Challenges and Contours of a Global Debate. Antipode, 44 (3), 932-949.

Munzer, S.R., Simon, P.C., 2009. Territory, Plants, and Land-use Rights Among the San of Southern Africa: A Case Study in Regional Biodiversity, Traditional Knowledge, and Intellectual Property. William and Mary Bill of Rights Journal, 17, 831-893.

Neumann, R., 1995. Ways of seeing Africa: Colonial recasting of African society and landscape in Serengeti National Park. Ecumene 2 (2): 149-169.

Neumann, R., 1997. Primitive Ideas: Protected Area Buffer Zones and the Politics of Land in Africa. Development and Change 28, 559-582.

Parmar, P., 2008. Revisiting the Human Right to Water. Australian Feminist Law Journal 28 (1), 77-96

Perelman, M., 2007. Primitive accumulation from feudalism to neoliberalism. Capitalism, Nature, Socialism 18 (2), 44-61.

Perelman, M., 2000. The Invention of Capitalism: Classical Political Economy and the Secret History of Primitive Accumulation. Durham: Duke University Press.

Resnick, D., 2009. The Benefits of Frame Resonance Disputes for Transnational Movements: The Case of Botswana's Central Kalahari Game Reserve. Social Movement Studies 8 (1), 55-72.

Roberts, A., 2008. Privatizing Social Reproduction: The Primitive Accumulation of Water in an Era of Neoliberalism. Antipode, 40 (4), 535-560.

Sarkin, J., Cook, A. 2012. The Human Rights Of The San (Bushmen) Of Botswana - The Clash Of The Rights Of Indigenous Communities And Their Access To Water With The Rights Of The State To Environmental Conservation And Mineral Resource Exploitation. Journal of Transnational Law \& Policy 20 (1), 1-40.

Saugestad, S., 2011. Impact of international mechanisms on indigenous rights in Botswana. The International Journal of Human Rights, 15 (1), 37-61.

Saugestad, S., 2006. News Notes on the outcome of the ruling in the Central Kalahari Game Reserve case, Botswana. Before Farming 2006 (4), 1-3.
Saugestad, S., 2001. The Inconvenient Indigenous: Remote Area Development in Botswana, Donor Assistance, and the First People of Kalahari. Centraltryckeriet Ake Svensson, Sweden.

Solway, J.S., 2009. Human Rights and NGO 'Wrongs': Conflict Diamond, Culture Wars and the 'Bushman Question'. Africa 79 (3), 321-346.

Solway, J.S., 1994. Drought as a Revelatory Crisis: An Exploration of Shifting Entitlements and Hierarchies in the Kalahari, Botswana. Development and Change 25, 471-495.

Sporton, D., Thomas, D.S.G. (Eds.) 2002. Sustainable Livelihoods in Kalahari Environments: A Contribution to Global Debates. Oxford University Press, Oxford and New York.

Sultana, F., Loftus, A. (Eds.), 2012. The Right to Water: Politics, Governance and Social Struggles. Earthscan, London and New York.

Survival International, 2010. April 1, 'Pioneering' plan to give Bushmen armbands as tourist lodge opens. www.survivalinternational.org/news/5705. (last accessed 25/05/2012).

Survival International, 2011a. January 27. Victory for the Kalahari Bushmen as court grants right to water. http://www.survivalinternational.org/news/6925. (last accessed 25/05/2012).

Survival International, 2011b. September 5. Borehole Breakthrough for Botswana's Bushmen. $\mathrm{http}: / /$ www.survivalinternational.org/news/7662. (last accessed 18/06/2013).

Swatuk, L. A., Rahm, D. 2004. Integrating policy, disintegrating practice: water resources management in Botswana. Physics and Chemistry of the Earth, Parts A/B/C 29 (15-18), 1357-1364.

Swyngedouw, E., 2005 Dispossessing H20: The contested terrain of water privatization. Capitalism, Nature, Socialism, 16 (1), 81-98.

Sylvain, R., 2008. "Land, water, and truth": San identity and global indigenism. American Anthropologist 104 (4), 1074-1085.

Taylor, J.J., 2007. Celebrating San victory too soon? Anthropology Today, 23 (5), 1-3.

Taylor, M., 2003. 'Wilderness', 'Development', and San Ethnicity in Contemporary Botswana. In: Hohmann, T., (Ed.) San and the State: Contesting Land, 
Development, Identity and Representation. Rüdiger Köppe Verlag, Köln, Germany, pp. 255-280.

Turner, M., 1999. No Space for Participation: Pastoralist Narratives and the Etiology of Park-Herder Conflict in Southeastern Niger. Land Degradation and Development 10 (4), 345-363.

United Nations General Assembly, 2010. July 28. Declaration on the Human Right to Water and Sanitation. (A/RES/64/292). http://daccess-ddsny.un.org/doc/UNDOC/GEN/N09/479/35/PDF/N0947 935.pdf. (last accessed 25/05/2012).

United Nations General Assembly, 2007. October 2. Declaration on the Rights of Indigenous Peoples (A/RES/61/295). http://daccess-ddsny.un.org/doc/UNDOC/GEN/N06/512/07/PDF/N0651 207.pdf. (last accessed 25/05/2012).
United Nations Human Rights Council, 2010. October 6. Human rights and access to safe drinking water and sanitation (A/HRC/15/9). http://daccess-ddsny.un.org/doc/UNDOC/GEN/G10/166/33/PDF/G1016 633.pdf. (last accessed 25/05/2012).

von Werlhof, C., 2000. 'Globalization' and the 'permanent' process of 'primitive accumulation': The example of the MAI, the Multilateral Agreement on Investment. Journal of World Systems Research 6 (3), 728-747

World Health Organization (WHO), 2011. Guidelines for drinking-water quality (4th ed).

http://whqlibdoc.who.int/publications/2011/978924154 8151_eng.pdf. (last accessed 31/03/2013).

${ }^{1}$ The indigenous peoples of the Central Kalahari Game Reserve have many names, including "Bushmen" which is considered derogatory (for a complete discussion, see Saugestad, 2001). The population involved in the legal case discussed in this paper is comprised of San groups, including, G/ui (or G/wi) and G//ana, and of Bakgalagadi (Hitchcock et al., 2011). For the purposes of this paper, which focuses specifically on the populations removed from the CKGR and later involved in the court cases at hand, we use "San and Bakgalagadi" (as used by Hitchcock et al., 2011; Saugestad, 2011; and Resnick, 2009), and at times "indigenous populations of the CKGR".

${ }^{2}$ As we detail in Section 2, there are a number of boreholes in the CKGR, including prospecting boreholes drilled by mining companies, most of which are under government control. However, the borehole at Mothomelo is particularly important in this case since it was included in the appellants' legal claims, which sought to "recommission, at their own expense, a borehole at Mothomelo in the Central Kahalari Game Reserve, and to sink other wells or boreholes in order to access water for domestic purposes, in accordance with s. 6 of the Water Act Cap 34:01" (Court of Appeal of Botswana, 2011).

${ }^{3}$ The relationship between San and Bakgalagadi historically has also been one of significant inequality, with the Bakgalagadi enjoying a better standing vis-à-vis the San (see Hitchcock, 2002 for complete discussion).

${ }^{4}$ The dominant ethnic group of Botswana (Sarkin and Cook, 2012; Good, 2008)

${ }^{5}$ Other boreholes in the reserve were drilled by mining companies as prospecting holes, such as the borehole at Mothomelo, drilled by De Beers Company (Court of Appeal of Botswana, 2011).

${ }^{6}$ At that time, mining was however permitted in the CKGR (Hitchcock et al., 2011, p. 68).

${ }^{7}$ In 1999 a Water Conservation strategy issued by Botswana's Department of Water Affairs outlined the official water policy around the scarcity of water resources. Freshwater was defined as scarce and vulnerable in the context of diminishing water resources, which ultimately called for usage restrictions imposed on mandatory basis (Department of Water Affairs, 1999, pp. 1-2). Furthermore, the national strategy for water conservation was centered almost entirely on the supply side of water resource management - a principle that reflected the government's policy of refusing to provide water to informal and remote settlements.

${ }^{8}$ These numbers are subject to some disagreement. For example, Taylor (2003) report 1600 people were relocated in 1997 and 350 in 2002 . Hitchcock (2002) reports over 1100 people were relocated in 1997, leaving 589 individuals in the CKGR (citing a 2001 census), followed by the relocation of some 450 people in 2002 with fewer than 70 people left in the CKGR. Saugestad (2001) notes 600 people were relocated from !Xade to New !Xade in 1997, by 2001 almost 2160 people had been relocated in total leaving approximately 500-600 people in the CKGR.

9 These, however, carry risks in terms of water quality. Note, for instance, that groundwater is considered 'improved' source of drinking water according to WHO standards for drinking water, while surface water is not, and is generally considered at high risk for microbial or other contamination (WHO, 2011).

${ }^{10}$ As part of nation-building efforts in light of South Africa's post-apartheid political climate, the government of Botswana does not support ethnic differentiation and therefore does not recognize San (and other groups) as 
indigenous peoples. The government of Botswana has not signed the International Labor Organization Convention 169, which specifically regards the rights of indigenous and tribal peoples in independent countries. In addition, Botswana initially opposed the United Nations Draft Declaration on the Rights of Indigenous Peoples, A/RES/61/295, but eventually voted in favour when the declaration came up for a vote in the UN General Assembly in 2007 (For more details see Cook and Sarkin, 2009). The government of Botswana however continues to refuse the differentiation of ethnic groups within the country (Hitchcock et al., 2011).

${ }^{11}$ Two noteworthy trends with regards to water access have since taken place in Botswana's Kalahari and deserve mention. First, it has been suggested that privatization of water services is currently unfolding in the resettlement camps, which is increasingly problematic for relocated San and Bakgalagadi populations. Furthermore, the government of Botswana continues to prioritize water allocation to the extractive industry (diamond mining) and the political elite (Swatuk and Rahm, 2004), which leads to decline in water supply to the resettlement camps, particularly /Xeri. Second, given an increasing push for diamond mining companies to recognize the impact of extractive activities for the socio-economic wellbeing of local populations (Sarkin and Cook, 2012, p. 37), some shifts towards corporate social responsibility (CSR) practices have been attempted by Gem Diamonds (previously DeBeers). Namely, Gem Diamonds has financed the revival of the previously decommissioned borehole at Mothomelo (Gem Diamonds, 2011a; 2011b; Survival International 2011b) as well as the drilling of additional boreholes in the CKGR. The company, which pursues its exploration and extractive activities at present, has reported that their CSR and sustainability programme will not only benefit local populations, but is also in line with their commitment to implement sustainable solutions for local ecosystems by providing water in more than one location and avoiding a "concentration of people around a single water source" (Gem Diamonds, 2011a; 2011b).

${ }^{12}$ We follow Brenner et al. (2010) and their assertion that neoliberalism is expressed through variegation and consider the events that unfolded in the CKGR as a tangible expression of neoliberalization, where stateenabling reforms (often termed re-regulation or roll-out neoliberalism) facilitated processes of capital accumulation and benefited private interests. Roberts (2008) similarly argues that neoliberalization can be illustrated by "a broader extension of global capital into new social and socio-environmental spaces and relations in the interest of capitalist accumulation" (p. 536; see also Bakker, 2010b).

${ }^{13}$ Private sector involvement in water supply is more likely to take place in urban settings given the potential profitability of densely populated urban areas and private interests' tendency to cherry pick (for a discussion regarding the case of Ghana see Amenga-Etego and Grusky, 2005). Evidence suggesting a stronger attraction towards urban settings does not proscribe establishment of private utilities in rural areas or other less-densely populated contexts per se, but deems it somewhat less likely.

${ }^{14}$ Instances where the HRW appears to have been crucial while privatization was not the issue can also be found in the literature. Consider for example the work of Parmar (2008) and Bywater (2012) both discussing the case of Plachimada located in the district of Kerala, India where local communities engaged the HRW to successfully protest the use and pollution of the groundwater tables by a subsidiary of Coca-Cola. 